\section{Election of IUPAC Officers and Bureau Members-Call for Nominations}

\begin{abstract}
$\mathrm{t}$ its General Assembly in Paris, France, on 10-11 July 2019, the IUPAC Council will be asked to elect a Vice President, a Secretary General, a Treasurer, and members of the Bureau to fulfill the vacancies created by retiring members. IUPAC National Adhering Organizations are invited to submit nominations no later than 31 March 2019.
\end{abstract}

On 1 January 2020 Christopher Brett (Portugal), Vice President and President-Elect of IUPAC, will become President. Qi-Feng Zhou (China), current President, will become Past President and remain an officer and a member of the Bureau for a period of two years, while Natalia Tarasova (Russia), current Past President, will retire. Secretary General Richard Hartshorn (New Zealand) and Treasurer Colin Humphris (UK) were both elected by the Council in August 2015 for a four-year term and are eligible to be nominated for an additional four-year term commencing in 2020. Nominations are invited.

In addition, there are this year five vacancies for Elected Members of the Bureau. Elected Members are elected to a four-year term, and are eligible for re-election to a second four-year term. No National Adhering Organization shall have more than one Elected Member on the Bureau, and the principle of fair geographical representation of Members shall be taken into account, as stipulated in the IUPAC Statutes.

Elected Members whose terms expire at the end of 2019 are:

- Prof. Mei-Hung Chiu* (China/Taipei) (2016-2019)

- Prof. Hemda Garelick* (UK) (2016-2019)

- Prof. Ehud Keinan* (Israel) (2016-2019)

- Prof. Kew-Ho Lee* (Korea) (2016-2019)

- Prof. Pietro Tundo* (Italy) (2016-2019)

*eligible for nomination

The following are Members whose terms continue to the end of 2021

- Prof. Russell J. Boyd (Canada) (2014-2017, 20182021)

- Prof. Javier García-Martínez (Spain) (2018-2021)

- Prof. Mary Garson (Australia) (2018-2021)

- Prof. Christopher K. Ober (USA) (2014-2017, 20182021)

- Prof. Ken Sakai (Japan) (2018-2021)
In addition to the five officers and the ten Elected Members, the Bureau also includes the eight Division Presidents (each elected by each individual Division), and five members representing the following Standing Committees, i.e. the Committee on Chemistry Education (CCE), the Committee on Chemistry and Industry $(\mathrm{COCl}), \mathrm{CHEMRAWN}$ (the Committee on CHEMical Research Applied to World Needs), the Interdivisional Committee on Terminology, Nomenclature and Symbols (ICTNS), and the Committee on Publications and Cheminformatics Data Standards (CPCDS).

IUPAC National Adhering Organizations are invited to submit nominations to the Secretary General via the Executive Director at <executivedirector@iupac.org> no later than 31 March 2019.

It is important for a vibrant organization that all vacant positions are filled after a fair and vigorous election process, so all nominations are encouraged. So, to make your voice heard, contact your National Adhering Organization and get involved.

A call for the general elections for the 2020-21 term was released earlier on 2 October 2018 and published in $\mathrm{Cl}$ Oct 2018.

\section{What Does the Bureau Do?}

The Bureau is established by the Council to act for the Union during intervals between meetings of the Council; it therefore fulfills important functions by ensuring continuity. The Bureau normally meets once a year. It consists of the officers (president vice president, secretary general, treasurer, and immediate past president), the division presidents, the chairs of the operational standing committees, and 10 other members elected by the Council. The elections should also allow for a fair geographical representation. In principle, no member country should have more than one elected member on the Bureau. The principal duties of the Bureau-as quoted in the statutes-are as follows:

- to ensure the strict observance of statutes and bylaws

- to prepare the agenda for meetings of the Council and in particular

- to make provision for elections

- to make recommendations thereon to the Council

- to attend the meetings of the Council

- to implement the decisions of the Council and execute the program of the Union as directed by the Council

- to take steps to ensure that international congresses of pure and applied chemistry are held 
- to take decisions about the holding of scientific meetings as proposed by the division committees

- to take all other steps necessary for the good conduct of the affairs of the Union

See the Bylaws for more details: https://iupac.org/who-we-are/ organizational-guidelines/

https://iupac.org/2019-election-iupac-officers-bureau-members-callnominations/

\section{Juris Meija Made the Top 40 Under 40}

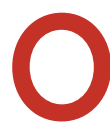
n 16 Oct 2018, The Analytical Scientist released their Top 40 Under 40 Power List celebrating the gifted young scientists making waves in analytical science. Among them is Juris Meija, the current Chair of the IUPAC Commission on Isotopic Abundances and Atomic Weights (CIAAW).

In his own words, Dr. Meija claimed that his greatest achievement has been his election as Chair of the Commission at age 33 and being part of the team to draft the new definition of the mole. As part of his research as an Officer in Metrology at National Research Council Canada, Ottawa, he explores the reliability of analytical data with a focus on isotope-based methods of quantitation. As Meija stated "it is all about the attention to detail in chemical measurements."

His prediction: We live in the era of big data, which often favors quantity over quality. This has undesirable effects on the reliability of chemical testing results. I believe that metrology will guide us away from the reproducibility crisis in analytical chemistry.

His advice: Nurture your social skills and be

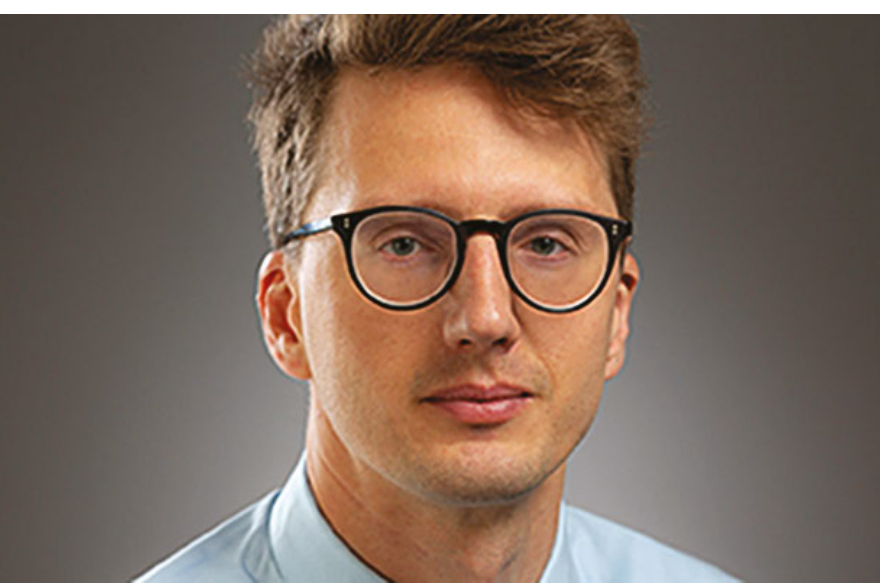

Juris Meija, Research Officer, Metrology, National Research Council Canada, Ottawa, Canada. someone others will want to work with.

All rising stars were nominated by The Analytical Scientist readers and shortlisted by an independent judging panel.

https://theanalyticalscientist.com/power-list/2018/

\section{Oliver Kappe is Awarded the 2018 IUPAC-ThalesNano Prize for Flow Chemistry}

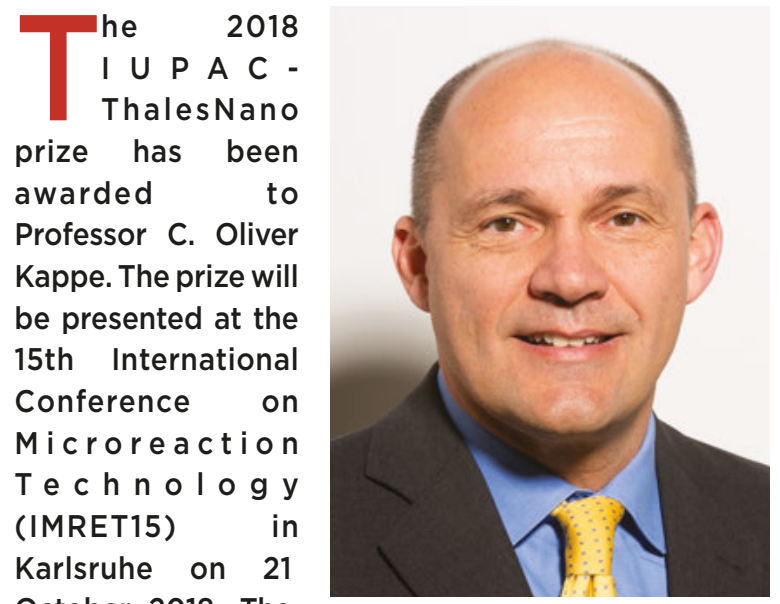

October 2018. The award address will

C. Oliver Kappe

be delivered at the Flow Chemistry Europe Conference in Cambridge, UK on 26 February 2019. The prize consists of an award of 10000 USD.

Professor Kappe is Professor of Chemistry at the University of Graz (Austria) and Scientific Director for Continuous Flow Synthesis and Processing (CC Flow) at the Research Center Pharmaceutical Engineering $\mathrm{GmbH}$ (RCPE). Professor Kappe has over 400 publications in the areas of continuous flow chemistry, application of microreactors, process intensification, and microwave-assisted reactions. He and his team have published syntheses with challenging systems and chemistry. He has served as an Ambassador for Flow Chemistry through his teaching, interdisciplinary work, and collaborations.

Professor Kappe holds a PhD in Organic Chemistry from the University of Graz. He completed postdoctoral research at the University of Queensland (Australia) and Emory University (United States). He has served as visiting scientist/professor at the Scripps Institute, Tokyo Institute of Technology, Sanford-Burnham Institute for Medical Research, and the Federal University of Rio de Janeiro. He is the founding editor and Editor-in-Chief of the Journal of Flow Chemistry. 